\title{
THE EFFECT OF TAKEOVERS ON THE EMPLOYMENT AND WAGES OF CENTRAL-OFFICE AND OTHER PERSONNEL
}

\author{
Frank R. Lichtenberg
}

Donald Siegel

Working Paper No. 2895

\author{
NATIONAL BUREAU OF ECONOMIC RESEARCH \\ 1050 Massachusetts Avenue \\ Cambridge, MA 02138 \\ March 1989
}

This research was performed at the Census Bureau's Center for Economic Studies with financial support from the National Science Foundation. We thank both organizations for their support. This paper is part of NBER's research program in Labor Studies. Any opinions expressed are those of the authors not those of the National Bureau of Economic Research. 
NBER Working Paper 2895

March 1989

THE EFFECT OF TAKEOVERS ON THE EMPLOYMENT AND WAGES

OF CENTRAL-OFFICE AND OTHER PERSONNEL

\section{ABSTRACT}

This paper presents evidence based on establishment-level Census Bureau data concerning the effects of ownership change on the employment and wages of both central office workers and manufacturing plant employees. We find that central offices that changed owners between 1977 and 1982 had substantially lower -- about 16\% lower -- employment growth during that period than central offices not changing owners. (There was, however, no significant difference in the growth of R\&D employment.) In contrast, employment growth in production establishments changing owners was only $5 \%$ lower than it was in production establishnents not changing owners... (The relative employment decline in production establishments changing owners occurred in the 2 or 3 years before the takeover; after the takeover, employment recovered a bit, but not enough to offset the previous decline.) This implies that the ratio of central-office to plant employees declines about $11 \%$ in firms changing owners: about 7.2 administrators per 1000 plant employees are eliminated. These findings are consistent with the view that reduction of administrative overhead is an important motive for changes in ownership. Failure to account for reductions in central-office employment results in a substantial (about $40 \%$ ) underestimate of the productivity gains associated with ownership change. We also provide evidence concerning the relationship between firm size and administrative-intensity.

Frank R. Lichtenberg

Graduate School of Business

Columbia University

726 Uris Hall

New York, NY 10027
Donald Siegel

National Bureau of Economic Research 1050 Massachusetts Avenue Cambridge, MA 02138 
During the 1980 s there has been a rapid increase in the rate of business ownership change in the United States. The value of the companies involved in such transactions increased almost sixfold between 1980 and 1986. The proliferation of takeovers bas stimulated growing interest (and in some cases concern) among policymakers, scholars, and the public about the causes and effects of ownership change, particularly about its effects on efficiency (hence "competitiveness").

One view of the process of ownership change is that takeovers (actual or threatened) are often necessary to force or allow significant changes in management practices, particularly substantial curtailment in (some of) the firm's activities. Shleifer and Vishny (1988, p.11), for example, argue that

hostile takeovers affect industries in decline or sharp change where managers fail to shrink operations rapidly enough or to make other adjustments. In maintaining full-scale operations, managers may be guarding the domain of their control or trying to protect employees from dismissal or wage cuts:

The group of employees that top executives may try hardest to protect are their immediate subordinates: managers and administrators employed at corporate or divisional headquarters. If so, a change in ownership would have a much greater impact on these employees than it would have on those lower down in the corporate hierarchy.

Prominent corporate "raiders" claim that this is indeed the case. Henry Kravis (1989, p. 71) makes the following statements concerning leveraged buyouts:

People who produce things will stay. We look at the people who report to people who report to people. We'll often cut fat at the corporate level. There'd be much less of this... if chief executives felt the pressure from their directors to do the cutting that they only do when they're threatened by takeover. 
In a similar vein, Carj Icahn (1989) asserts that we have

created a corporate welfare state... companies are burdened by layers of vice presidents who not only don't produce, but are often counterproductive...II and other "raiders" usually eliminate the people who are most responsible for the wess - the "Top Brass"... In 1986 , I took control of T. H.A... and managed to eliminate more than $\$ 300$ million a year in waste and bureaucracy.

This kind of "restructuring" can occur in the absence of a major shock to the organjation, such as a takeover or bankruptcy. General

Electric and Monsanto provide two recent examples of this:

[The chief executive of General Electric turned] GE from a textbook case of a massive, bureaucracically managed conglomerate into a new model of decentralised, Iiberated management... He has dispensed wh layers of headquarters staff, cutting it from 1700 to 1000 by removing the administrators that acted as filters between each business unit and the boss's office.

Monsanto's main organisational change in its factories has been to do away with most of its foreqan, supervisors, and quality inspectors and instead to invite plant workers to oversee themselves... Another useful change has been to give workers contact with their customers, so that they know where the product goes and why... Previously, they would have gone through the sales staff.

Athough these specific reductions in administrative overhead occurred in the absence of takeovers, we hypothesize that in general such reductions are much more likely to occur in fims experiencing changes in corporate control than in other firns.

In this paper we cest this and other hypotheses by providing estimates of the effects of takeovers on the employment and wages of employees in both auxiliary establishments (which include central administrative offices) and production establishments. These estimates are obtained via econometric analysis of large longitudinal data sets

1 The Economist (1989, P. 55).

2 Ibid, P. 56. 
based on Census Bureau surveys or censuses of both types of establishments: For each type of establishment, we estimate differences between establishments changing and not changing owners in the growth of employment and wages, so we can contrast the effects of takeovers on auxiliary- and production-establishment employees... We can also identify the effects on a smali but important subset of personnel - employees engaged in research and development (RED) - - and distinguish between the effects on production and nonproduction workers in production establishments.

There is a small previous literature on the labor impact of ownership change, but no previous studies have examined administrative employment separately. In Section II we briefly review the existing evidence. In Section III describe the nature of our data and provide some background and historical information about auxiliary-establishnent. employment and wages. The core of our empirical investigation is contained in Section IV. There we provide descriptive statistics, a discussion of methodological issues, and presentation and interpretation of our econometric estimates. In Section V we consider theory and evidence concerning the relationship between firm size and administrative-intensity (the fraction of employees engaged in administration). A sumary and conclusions appear in Section VI:

II. Previous research on the labor impact of ownership change We are aware of three previous studies - all of which examined firm- or plant-level data -- that provided evidence concerning the labor impact of ownership change. The first was our 1987 paper on productivity and changes in ownership of manufacturing plants, which analyzed longitudinal Census data for almost 20,000 establishments. Although the effect 
of owersing change on totainactor productivity (TFP) was the primary emphasis of the study, we also presentred estimates of differences in the growth of total labor input, ${ }^{3}$ duxing each of the years $t-7$ to $t+7$, between plants changing owners in year $t$ ("changers") and plants in the same industry not changing owners in year " ("nonchangers"). The data indicated that "changers" bad significanty lower labor input growt rates than "nonchangers"-in years $t-2, t-1$, and - - the respective diferences were $-0.8,-2.2$, and -4.1 percentage points - but sighty tigher growth races in years $t+1, t+2$, and $t+3(0.4,1.0$, and 0.6 perm centage points). From about 2 years before to $2^{\frac{2}{2}}$ years after the owersip chagg, mean labor input of "changers" declines 5.1 percent. relative to that of "nonchangers." But the decline occurs largely if not entirely before the change in ownership; after the change, there is a relative increase in labor input, although too small an increase to completely offset the previous decline.

Our previous paper did not contain any evidence about the behavior of wages or compensation (wages plus supplements) in connection with ownership change, nox did it distinguish between production and nonproduction employees. Moreover, the analysis was based only on data for manufacturing (production) establishments; central administrative offices, which in 1982 accounted for 10.0 percent of manufacturing payrolis, were not included. If the effects of ownership change on

3 Total labor input was defined as "production-worker-equivalent manhours," i.e. as producticr-worker manhours times the ratio of total wages and salaries to production-worker wages.

4 Almost ali of these differences were due to differences in employment growth, rather than differences in growth of average annual hours of work. 
employment in production establishments and in administrative offices differ substantialiy, then failure to account for administrative offices way result in seriously biased estimates of the effects on TEP. In this paper we estimate the effects of ownership change on employment and wages in administrative offices and contrast them with the corresponding effects in production establishments. This comparison is of interest in its own right, and it also enables us to assess and eliginate the bias to which our earlier productivity estimates were subject. We also re-examine the labor impact of ownership change in production establishments in greater detail.

The second study that provides evidence on the labor impact of changes in ownerstip is Kaplan's (1988) analysis of a sample of 33 large (over $\$ 50$ million) management buyouts of public companies completed between 1980 and 1986 . Kaplan compared the number of employees at the end of the first full post-buyout year in wich employnent numbers were reported with the number of employees in the year before the buyout. 5 He found that the median employment change for all 33 firms was $0.0 \%$, but the median industry-adjusted employment change was $-15.3 \%$, i.e employment growth among buyout firms was 15.3 percentage points below growth among non-buyout firms in the same industry. When he restricted the analysis to 22 firms not engaged in extensive post-buyout acquisition and divestiture activity, the raw and industry-adjusted median employment changes were $3.3 \%$ and $-11.4 \%$, respectively. Thus Kaplan's much smaller and more narrowly-focused data set revealed declines in relative employ-

5 Kaplan did not have access to wage data. 
ment about 2 to 3 times greater than ours did, and over a narrower "event window."

The thixd study of ownership change, by Brown and Medoff (1988), is the only one whose principal focus is on its effects on labor, and is the only one to provide estimates of wage effects. These authors analyzed guarteriy employment and payroll data contained in unemployment insurance records kept by the Kichigan Employnent Security Comission. As they acknowledge, an important disadvatage of this data set is that it covers only a single state. Consequently, the data do not reflect what is happening in other locations of mutistate companies, and few large acquisitions are recorded in their data. Brown and Medoff distinguished three kinds of ownership change: (1) "simple sales": firm A changes ownership without being integrated with any other firm; (2) "assets-only sale" firm A purchases the assets of firm B without absorbing its workforce; and (3) "merger": firm A purchases firm $B$ and (at least initially) absorbs (nost of) firm B's workers, or firm A and firm $B$ combine to form firm $C$, with (at least initially) firm $C$ including (most of) the workers of firms $A$ and $B$. Their estimates of the employment and wage changes associated with each type of transaction are as follows:

$$
\begin{array}{ll}
\text { employment } & \begin{array}{l}
\text { wage } \\
\text { change }
\end{array} \\
\frac{\text { change }}{-5 \%} &
\end{array}
$$$$
\text { simple sale }
$$$$
\text { assets }-0 \text { nly sale } \quad-5 \% \quad+5 \%
$$

merger $+2 \% \quad-4 \%$

Farber (1988) observed that the fact that transactions were classified on the basis of employment changes makes it difficult to interpret the employment effects, and the authors themselves acknowledge that the estimates of these effects are sensitive to specification details; the wage effects were less ambiguous. Because only about $1 / 3$ of these 
transactions were assets-only sales, their estimates imply that on average wages fall slightly - about 1 or 2 percent - in connection with ownership change. They observe that in the case of mergers, the wage decline may partly be due to the departure of the relatively highly-paid bead of the acquired firm.

Auerbach (1988, p. 2) suggested that perhaps the most important conclusion that can be drawn from the Brown and Medoff study is that the employment and wage changes associated with ownership change are of "relatively small magnitude." But even if the effect of ownership change on overall employment and wage rates is small, it may have a sizeable impact on the employment and wage of specific types of workers. Our data enable us to determine the effects of ownership change on a relatively smal1, but key, subset of employees those who work in auxiliary estabIishments - the locus of employment for many top managers, administrators, and R\&D personnel.

\section{Data and descriptive statistics}

The empirical analysis described in this paper is based on three distinct data sets, each based on a different Census Bureau census or survey of establishments or firms. The first data set is based on "Auxiliary Establishment Reports" collected in the course of the 1977 and 1982 Economic Censuses. Researchers have not, to our knowledge, previously analyzed these data at the micro level. The Census Bureau defines auxiliary establishments as those

whose employees are primarily engaged in general and tusiness administration; management; research; development, and testing; warehousing; electronic data processing; and other supporting services performed centrally for other establishments of the 
same company rather than for other companies or the general public.

The primary functions of these establishnents are to manage, administer, service or suppors the activities of the other establishents of the company.

The Ceasus of audiliary establishments collects data on the number of employees, by type of work perfomed, anual payroll, depreciable assets, capital expenditures, and other variables and attributes of the establisbment. In 1982, there were almost 36,000 auxiliary establisments, and almost 2.6 million people were employed in them. Table 1 shows the 1982 distribution of andiary establishment employees by type of work performed. About onemtitird of employees are classified as "administrative and mangerial." 8 The principal activity of 9.3 percent $(240$ thousand) of these employees was research, development, and testing. 9

We obtained data for the entire set of auxiliary establishments in each of two adjacert Census years - 1977 and 1982 - and when records for a given establishent (identilied by a unique estabishment code) were present in both years, we linked then together. ${ }^{10}$ Each record also contains a code identifying the parent compay that owns the establish-

6 U.S. Bureau of the Census $(1986, \mathrm{P} . \mathrm{A}-1)$.

7 U.S. Bureau of the Census $(1986$, p. 2).

8 In contrast, according to the Current Population Survey, about 11 percent of all nonfarm employed persons identify themselves as managers and administrators. See U.S. Bureau of Labor Statistics $(1980, p .34)$.

9 The National Science Eoundation, on the basis of its annual suryey of industrial RaD, estimates that there were 510 thousand full-time-equivalent scientists and engineers engaged in RGD in industry in 1982 .

10 As discussed below, a substantial fraction of the estabishments that were ever observed were observed in only one year, presumably due to closing and opening of establishments. Since 1982 was a very severe recession year, our sample period is probably not representative of the entire recent postwar era. 
ment.. We assumed that the establishment's owner changed if and only if there was a change in the value of this code between 1977 and 1982. This procedure is probably subject to both type I and type II error: some non-matches of the code may be due to coding errors, and certain ownership changes may not result in changes in the code. Measurement error contained in our indicator of ownership change is likely to bias towards zero the estimated differences in behavior between establishments changing and not changing owners. Unfortunately, the data don't permit us to classify ownership changes into different "types", e.g. hostile versus friendly takeovers.

The data set described above enables us to contrast the employment and wage behavior of auxiliary establishments changing owners with that of auxiliary establishments not changing owners. We also wish to contrast the former with the behavior of production establishments changing owners. Ta accomplish this we utilize a second data set, the Longitudinal Establishment Data (IED). This data set, based on the Annual Surveys and Censuses of Manufactures, contains annual data for the years 1972-81 on the output and inputs of almost 20,000 manufacturing (production) establishments. It was the basis for our previous (1987) study of productivity and ownership change, and also for Lichtenberg's (1988) study of internal costs of adjustment, and is described in detail in those two papers.

Table 2 presents data on the aggregate employment and payroll of both auxiliary and production establishments in manufacturing, for Census years from 1963 to 1982. Auxiliary-establishment employment grew much more rapidly than production-establishment employment. The number of auxiliary-establishment employees per 100 production-establishment 
employees increased from 4.5 in 1963 to 7.2 in 1982 . Payroll per employee is much bigher in auxiliary than in production establishents, but toe gap has been carrowing: auxiliary establishment employees on average earned 68 pescent wo 1963 , but onjy 56 percent more in 1992.

\section{W. Empirica analysis of the effects of takeovers}

We begin our empirical analysis of the labor impact of owershp change by considering the data presented in Table 3 on mean values of employment and wage levels and changes, 1977-82, by status of auxiliary estabiatinent. ${ }^{11}$ The four atualy exclusive, exhaustive statuses and the criteria for assigning them to aumiliary establishents were as follows: (1) "no change": the establishment was present in both 1977 and 1982 censuses and had the same owner ID; (2) "changed owners": the establishment was present in both years and had different IDs; ( 3 ) "closed": the establishment was present in 1977 only; (4) "opened": the establishment was present in 1982 only. Previous studies have documented the high rate of closing and opening of production establishments between census years. For example, Dunne, Roberts, and Samuelson (1988, Table ib) estimated that 25 to 40 percent (depending on plant age) of the manufacturing establishments present in a given census had closed by the next census. Table 3 indicates that a similar "failure rate" ( 36.3 percent in manufacturing) applies to auxiliary establishments. Also as in the case of production establishments, auxiliary establishments that close are smaller on average than those that survive.

11 Because we will want to contrast the effects of takeovers on auxiliary establishments with their effects on production establishments, and we lack data on nonmanufacturing production establishments, we present estimates for auxiliary establishments only in manufacturing as well as for those in all industries. 
Despite the fact that the number of establishments closing and opening is large relative to the number of surviving establishments, and very large relative to the number changing owners, in the remainder of this paper we analyze only the data on surviving establishments. Because we observe establishments that close or open only once, we cannot compare their employment or wage changes with those of surviving plants. One might hypothesize that the probability that an establishment closes is related to whether or not it changes owners. In their study of mergers and acquisitions in the New Jersey economy, however, Yago and Stevenson (1986) found no evidence of plant closings occurring as a result of hostile takeovers. Also, Brown and Medoff (1988, pp. 22-23) reported that including firms that "died" in their sample did not materially affect their results. 12

Among the surviving establishments, those that change owners are smaller and pay lower wages than those that do not. 10.5 percent of all surviving auxiliary establishments, and 10.8 percent of those in manufacturing, changed owners. To calculate the percent of employees affected by changes in ownership, we can weight the number of establishments by their respective mean employment; in manufacturing, the proportion of employees affected is 6.5 percent 13

Perhaps the most interesting statistics in Table 3 are the mean growth rates (changes in logarithms) of employment and wages Employment growth in auxiliary establishments that changed owners was 19 percent

12 See Lichtenberg and Siegel (1987, pp 661-2) for a discussion in a slightly different context of the effect of censoring failing establishments.

13 Brown and Medoff found that 16 percent of all workers sampled were involved in a change in ownership over a five-year period. 
lower (16 percent in the case of mamfacturing establiswents) than it was in establishments that didn't change owners. Moreover the latter experienced modest positive growth whereas the formet experienced sharp decines in employment. Establishments changing owners also had lower growth rates of nominal wages, arthough only in the case of manufacturing establishments is the difference nonnegligible - 4.4 percentage points. 14

The differences between growth rates are interesting and suggestive, but for at least two reasons one might believe that the simple differences are biased estimates of the true effects of ownership change. First, the data analyzed in Table 3 were not standardized by industry. If the incidence of ownership change is greater in industries with aboveor below-average employment growth, then differences between unstandardized growth rates may provide a distorted picture of the impact of ownership change on employment. Blair (1988) found that the level of merger activity tends to be higher in industries experiencing lower employment growth, suggesting that the estimates reported above overstate the industry-adjusted differential.

Second, it is well known that there is a strong negative correlation between the initial size of firms and their subsequent growth rates. Hall ( 1987 , p. 603) has recently shown that "neither measurement error in employment nor sample attrition can account for the negative coefficient on firn size in the growth rate equation." Since establishments changing owners are smaller than those not changing owners, in the absence of any

14 The change between 1977 and 1982 in the logarithos of the Consumer Price Index and of the GNP Implicit Price Deflator were .466 and .390 , respectively. 
effect of ownership change on employment growth one would expect the former to exhibit higher employment growth. The employment-growth differences shown in Table 3 would therefore underestimate the effect of ownership change.

We can eliminate both of the potential biases (which may be offsetting) by estimating regression models of the form

$$
\ln x_{i j t}=\beta_{1} O C_{i j t}+\beta_{2} \ln x_{i j t-5}+\gamma_{j}+u_{i j t}
$$

where $X$ denotes either employment or wages; the subscript ijt refers to establishment $i$ in 4 -digit SIC industry $j$ in year $t$; OC equals 1 if the establishment changed owners between $t-5$ and $t$, and otherwise equals zero; and is a classical disturbance. Simply comparing the growth rates of establishments changing and not changing owners is equivalent to imposing the restrictions $\beta_{2}=1$ and $\gamma_{j}=y, \forall_{j}$. We now relax those restrictions.

Estimates of the parameter $\beta_{1}$ in equation ( 1$)$, for auxiliary establishments in both all industries and in manufacturing, and production establishments in manufacturing, are reported in Table 4 . Relaxing the restrictions reduces slightly the estimated employment effect of changes in ownership of auxiliary establishments the mean relative employment of establishments changing owners declines about $16-17$ percent. In contrast, relaxing the restrictions has a substantial impact on the estimated wage effects: controlling for industry and the initial wage level, mean wage growth of auxiliary establishments changing owners is 9.2 percentage points lower $(6.0$ percentage points in manufacturing) than that of establishments not changing owners. These estimates imply that employment and real wages fell significantly more in auxiliary 
estabiishments changing owners between 1977 and 1982 than in those that did not.

In addition to estimating the effect of ownership change on the total employment of auxiliary establishments, for a subset of establishments we can also estimate the effect on RED employment, i.e. the number of persons whose principal activity is research, development, and testing. As Auerbach $(1988, "$ p. 3-4) notes, some parties to the popular and policy debates about takeovers are concerned that takeovers, actual or threatened, may reduce investment in long-term projects, particularly RAD. We have estimated equation (1) -- defining $X$ as R\&D employment -for the subset of 1099 establishnents in all industries that reported positive values of this variable in both years. ${ }^{15}$ The point estimate (t-statistic) for $\beta_{1}$ from this equation is -.039 $(0.5)$. The estimate is less than one-fourth as large in magnitude as the corresponding estimate for total employment, and it is far frow statistically significant. Hence we cannot reject the null hypothesis of no difference between establishments changing and not changing owners in the growth of R\&D employment. This finding is consistent with that of $\mathrm{Hall}$ (1988), who "found very little evidence in the existing data (through 1985) that acquisitions cause a reduction in R\&D spending; in the aggregate, firms involved in mergers showed no difference in their pre and post-merger R\&D performance over those not so involved."

In order to contrast the effects of ownership change on auxiliary establishments with its effects on production establishments, we also 
estimated equation (1) using the LED for production establishments, 16 the results are shown in the last line of Table 4 . Ownership change is associated with relative declines in employment and wages in production establishments, but the magnitudes of the declines is only about one-third those for auxiliary establishments. The growth rate of employment is 4.5 percentage points lower for production establishments changing owners between 1976 and 1981 than it is for other production establishments, controlling for industry and initial size. As noted earlier, production establishments changing owners tend to have higher employment growth in the first several years after ownership change than production establishments that have not changed owners; the negative net effect of ownership change on 5-year employment growth is due to large relative employment declines immediately preceeding the change 17

The wage effects shown in Table 4 are based on the definition of the wage as payroll per employee, i.e. supplementary labor compensation is excluded. In the case of production establishments, we were also able to estimate the model for $X$ defined as total compensation (payroll plus supplementary compensation) per employee. Using this more comprehensive wage measure changes the estimated wage effect $\beta_{1}$ (and its t-statistic) from $-.021(4.7)$ to $-.029(7.8)$. The relative decline in total compensation per employee is 38 percent greater than the relative decline in payroll per employee. Because the ratio of aggregate supplementary labor

employment in 1982, and the number going from positive to zero $R \& D$ employment.

16 Data limitations forced us to define $t$ as 1981 rather than 1982.

17 Because we observe auxiliary establisbments only twice, we cannot determine for them the extent to which the decline in relative employment and wages occurs before vs. after ownership change. 
compensation to aggregate total compensation is about .2 , this implies that the effect of ownership change on suppiements per employee is -.06I, about three times as great as its effect on payroll per employee.

The difference between the employment effect of owership change in auxiliary and production establishments has some interesting and important implications. Let $\Delta$ represent the difference between estabIishments changing and not changing owners, A represent auxiliary-establishment employment, $P$ represent production-establishment employment, $R$ represent their ratio $\mathrm{A} / \mathrm{P}$, and let dot superscripts represent growth rates. Then

$$
\Delta \dot{R}=\Delta \dot{A}-\Delta \dot{P}=-.157-(-.045)=-.112
$$

so that ownership change reduces the ratio of auxiliary establishment employment to production establishment employment by 11.2 percent. As Table 1 shows, the simple avarage of the 1977 and 1982 aggregate values of this ratio is $(5.8+7.2) / 2=6.4$ percent. Evaluated at this population mean, the 11.2 percent reduction in $R$ implies the elimination of about 7.2 auxiliary establishment jobs for every 1000 production establishment jobs. This reduction in $\mathrm{R}$ is consistent with the examples of "restructuring" described earlier in the paper.

In our earlier study of the effects of ownership change on total-factor productivity, the measure of labor input we used did not account for auxiliary establishment employtent; it was based only on production establishment employment. Because ownership change results in a reduction in $R$, we underestimated the true relative decline in labor input, and the true relative increase in TFP, that occurs in connection 
with ownership change. The difference in the growth in true labor input $L^{\circ}$ is

$$
\Delta^{*}=S_{A} \Delta \dot{A}+\left(1-S_{A}\right) \Delta \dot{P}=\Delta \dot{P}+S_{A}(\Delta \dot{A}-\Delta \dot{P})=\Delta \dot{P}+S_{A} \Delta \dot{R}
$$

where $S_{A}$ is the share of auxiliary establishment payroll in total (auxiliary- plus production-establishment) payroll. The mean of the 1977 and 1982 aggregate values of $\mathrm{S}_{\mathrm{A}}$ is equal to 9.2 percent. Before our measure of labor input growth was simply $\ddot{\mathrm{P}}$; the error $\varepsilon$ in our measure was

$$
\varepsilon=\Delta \dot{L}^{t}-\dot{\Delta P}=S_{A} \Delta \dot{R}=(.092)(-.112)=-.0103
$$

Since $\Delta \vec{P}=-045$, this represents a percentage error of about 23 percent. To assess the resulting error in the estimate of the effect of ownership change on TFP growth, we need merely to multiply $E$ by $(-1$ times) labor's share in gross output, which is approximately $1 / 3$. Because true relative labor input fell 1.03 percentage points more than we had estimated, true relative TFP increased .34 percentage points more than we had estimated. We had previously estimated that ownership change is associated with relative TFP increases of 42 to .51 percentage points 18 Thus, our estimate of the effect of ownership change on TFP is increased about 75 percent -- from .46 to .80 percentage points -- when we properly account for changes in auxiliary-establishment employment.

The preceding calculations were implicitly predicated on the assumption that the differences in employment growth between firms involved and not involved in ownership change is identical to the difference between

18 See Lichtenberg and Siegel (1987, p. 660). 
establishments involved and not involved in ownership change. It is possible, though, that when a firm acquires an administrative office, it transfers or reassigns some of its employees to offices it already operates. If that were the case, we would have overestimated the net decline in relative administrative employment accompanying ownersuip change. In order to investigate this possibility, we generalized equam tion (1) to inciude additional regressors, including a dumy variable equal to one if the 1982 ownex of the estabisbment had acquired other auxiliary establishments since 1977, and otherwise equal to zero. A positive coefficient $\left(\beta_{3}\right)$ on this variable would be consistent with the hypothesis of transfers of employees from acquired establishments, although it could aiso simply reflect that firms acquiring establishments are also otherwise growing more rapidly (e.g., by building new production establishments). When this variable was included in the employment equation, the estimates of $\beta_{1}$ and $\beta_{3}$ were as follows:

$\begin{array}{lll}\text { All industries } & \frac{\beta_{1}}{-.180} & \frac{\beta_{3}}{.007} \\ (8.0) & (0.4)\end{array}$

Manufacturing $\quad-.192 \quad .074$

The coefficient $\beta_{3}$ is far from significant in the regression estimated on establishments from all industries. In the case of manufacturing, however, it is positive and significantly different from zero, indicating that auxiliary establishments owned by firms that have been acquiring other auxiliary establishments experience above-average growth in employment. The magnitude of $\beta_{3}$ is only 39 percent as large as the magnitude of $\beta_{1}$, but the initial size of establishments owned by firms that have 
been acquiring other establishments is probably greater than the initial size of acquired establishments.

To calculate the extent to which reductions in employment in acquired auxiliary establishments might be offset by increases in employment in other auxiliary establishments owned by the acquiring firm, we need data on (1) the proportion $\pi$ of cases of auxiliary-establishment acquisition in which the acquiring firm owns other auxiliary establishments, and (2) the ratio $\theta$ of mean initial employment of acquired establishments to mean initial employment of other establishments owned by acquiring companies our estimate of the difference $\Delta A_{f}$ between auxiliary establishment employment growth in firms involved and not involved in acquisitions would be $\Delta A_{f}=\beta_{1}+\pi \cdot \theta \cdot \beta_{3}$. Unfortunately, direct data on $\pi$ and $\theta$ are not available at this time, and we are therefore forced to use crude proxies. Our proxy for $\pi$ is simply the proportion of all auxiliary establishments (not just ones that changed owners) that are owned by firms that own more than one auxiliary estabIishment; this fraction is approximately $2 / 3$. Our proxy for $\theta$ is the ratio of mean 1977 employment for "no change" establishments to the mean for establishments that changed owners; as shown in Table 4 , this ratio is $156.3 / 93.2=1.68$. Hence $\Delta A_{f}=-.192+(.67)(1.68)(.074)=$ -.109 , and our estimate of the magnitude of the effect of ownership change on relative auxiliary-establishment employment is reduced by about a third, from -.157 (from Table 3) to -.109 . We have not investigated whether employment growth in production establishments owned by firms that are acquiring other production establishments is above- or 
below-average, but we assume that this is not the case, and therefore that -.045 is a valid estimate of $\Delta \dot{P}$. Then the magnitude of our estimates of $\triangle P$ and $\varepsilon$ is reduced by 43 percent to -.064 and -.0053 , respectively. The correction to our previous paper's estimate of the relative TFP increase associated with ownership change is also proporcionately reduced, from 32 to .18 percentage points. Our admittedly crude attempt to adjust for employment growth in nonacquired establishments of acquiring firms thus reduces the size of the effects of interest, but it does so only in manufacturing, and even there the effects remain sizeable after adjustment.

Up until now we have been analyzing one kind of relative-employment effect of ownership change: its effect on the ratio of auxiliary-establishment employment to production-establishment employment. As we noted earlier, the Census data enable us to distinguish between two different types of employees in production establishments: production and nonproduction workers. About one-fourth of production-establishment employees are nonproduction workers. Nonproduction workers in production establishments (denoted NP) may be more similar to auxiliary-establishment employees (denoted $A$ ), in terms of the nature of their work and their earnings (skill) levels, than they are to production employees in production establishments (denoted PP). 19 $16.5,25.2$, and 29.8 thousand dollars, respectively. 
We therefore consider next the effect of ownership change on the ratio NP/PP and also on $($ NP + A)/PP. 20

Because we have annual - as opposed to merely quinquennial -- data on production establishments, our method of analysis will differ slighty from the one developed earlier. Our procedure is to estimate regressions of the form

$$
\ln x_{i j, t+k}=\beta_{k} O C_{i j t}+\gamma_{j}+u_{i j, t+k}
$$

where $\mathrm{X}$ denotes either $\mathrm{P}(=\mathrm{PP}+\mathrm{NP}), \mathrm{PP}$, or $\mathrm{NP}$; the subscript $i j, t+k$ denotes establishment $i$ in industry $j$ in year $t+k(k=-5,-4, \ldots,-3,+4) ; O C_{i j t}$ equals $I$ if the establishment changed owners between $t-1$ and $t$, and otherwise equals zero; $\gamma_{j}$ is a "fixed effect" for industry $j$; and $u$ is a classical disturbance. Hence $\beta_{k}$ is the percentage difference in the mean value of $X$ in year $t+k$ between establishments changing and not changing owners between $t-1$ and $t$. Estimates of the $\beta_{k}$ are reported in Table 5 . The figure -.082 in the first row and column indicates that establishments that will change owners between four and five years later on average employ 8.2 percent fewer workes than those that will not change owners. As in the case of auxiliary establishments, the probability of future ownership change is inversely related to current size. The first column clearly documents the fact noted earlier, that the relative total employment of plants changing owners declines sharply until immediately after the change, and then increases slightly. 21

20 This analysis will not have implications for our previous measures of labor-input or TFP growth, since these were already based on an appropriately- (relative-wage-) weighted index of $\mathrm{PP}$ and $\mathrm{NP}$.

21 The relative wage -- payroli pez employee -- displays a similar pattern, falling from -.020 in year $t-5$ to -.039 in years $t-1$ and $t$, and then increasing slightly to -.036 . 
As columns 2 and 3 of Table 5 show, the data on total employment mask very different patterns for production and nonproduction employment. Whereas plants changing owners on average employ $7-13$ percent fewer production workers than plants not changing owners in every year fron $t-5$ to $\$ 4$, they employ $1-2$ percent more nonproduction workers in every year, and the differences are mostly significant. The ratio of nonproduction to production employees is $9-16$ percent higher in plants changing owners. Moreover, the decline in relative employwent prior to ownership change, and the partial subsequent recovery, is confined almost entirely to production-worker employment. There is very little movement over time in the relative employment of nonproduction workers.

In order to obtain estimates of the effects of ownership change on $\mathrm{PP}$ and NP workers that are comparable to our estimates of the effects on A workers, we compute averages of the 5 five-year differences $\beta_{0}-\beta_{-5}$, $\beta_{1}-\beta_{-4}, \ldots, \beta_{4}-\beta_{-1}$. Estimates of the effect of ownership change on five-year relative-employment growth, for $P P, N P$, and $A$, are as follows:

$\begin{array}{ccc}\text { type of worker } & \begin{array}{c}\text { unadjusted } \\ \text { estimate }\end{array} & \begin{array}{c}\text { adjusted } \\ \text { estimate }\end{array} \\ \text { PP } & -.036 & - \\ \text { NP } & -.001 & - \\ \text { A } & -.157 & -.109\end{array}$

Whereas the relative decline in $A$ associated with ownership change is apparently much greater than the relative decline in $P P$, the relative decline in NP is essentially zero. In 1982 there were 10.3 A workers and 43.7 NP workers per 100 P workers in manufacturing, so the mean value of the fraction $a=A /(A+N B)$ is .191 . Hence the relative decline in the sum $\mathrm{S}=\mathrm{A}+\mathrm{NP}$ is 


$$
\Delta \dot{S}=a \Delta \dot{A}+(1-a) \Delta \dot{N P}=-.030
$$

which is close to, indeed slightly less than, the mean relative decline in production-worker employment $\Delta \dot{\mathrm{P}}=-.035$. Although the ratio of auxiliary-establishment employees to production workers declines sharply in connection with ownership change, the ratio of total "indirect" labor $(A+N P)$ to "direct" labor $(P)$ does not - in fact, it appears to increase slightly -- due to the negligible effect of ownership change on the employment level of nonproduction workers in production establishments.

v. The relationship between firm size and administrative intensity

Table 2 provided aggregate time-series data on the relationship between auxiliary-establishment employment and production-establishment employment. We believe that firm-level cross-sectional data characterizing this relationship are also of interest. A number of economists and organization theorists have developed theoretical models of the hierarchical or administrative structure of organizations, which have testable implications for the relationship between the number of administrative employees A and the number of production employees P. Starbuck (1964, P. $499)$ observes that early organization theorists tended to view the administrative structure as a pyramidal hierarchy. One man comprises the top level in this hierarchy; he has $S$ subordinates who comprise the second level; each of these has S subordinates, giving $S^{2}$ people in the third level; and so forth. (S is referred to as the "span of control.") The total number of administrators in a hierarchy with $\lambda$ levels is $A=$ $\left(S^{\lambda}-1\right) /(S-1)$. If there are $\sigma$ production workers per foreman then the 
total number of production workers is $\mathrm{P}=0 \cdot \mathrm{S}^{\lambda-1}$, and total employment is

$$
T=A+P=\frac{S^{\lambda}-1}{S-1}+\sigma \cdot S^{\lambda-1}
$$

Starbuck showed that, for plausible, assumed values of $S$ and 0 , the ratio A/P would be essentially independent of $T$ (or $\lambda$ ) for values of $T$ above a relatively low threshold (i.e., $I=100$ ). In other words, increasing the number $\lambda$ of hierarchical levels of an organization (hence its size $\mathrm{T}$ ) would generally not result in an increase in the proportion of administrative employees. 22 Similarly; Becknann (1977, p. 1) argued that the claim that "increasing size of the organization burdens every productive worker with an ever increasing number of administrators per production worker" was not theoretically valid. Previous theorists, such as Knight and Kaldor, had hypothesized that there are increasing costs of administration per worker; in the presence of increasing returns to production activities (which they also hypothesized), the existence of an optimal firm size required there to be diseconomies of administration.

Existing evidence on the relationship across organizations between administrative-intensity $(A / P)$ and size (T) is very limited. Starbuck (1964, EP. 501-2) cites four studies: one of California school districts, which found a positive relationship, two of firms, which found essentially no relationship, and one of 30 organizations of various

22 The proportion of administrators could even by a decreasing function of size if the span of control $S$ tended to be greater in larger organizations, as some fragmentary evidence indicated. 
kinds, which found a slightly negative relationship. We seek to shed further light on this relationship by examining the correlation across firms between total firm employment and either (a) total employment in auxiliary establishments or (b) managerial and administrative employment in auxiliary establishments. Data on total firm employment were obtained. from a third data source, the NSF/Census Survey of Industrial R\&D. 23 Parent-company identification codes were used to aggregate auxiliary establishment employment data to the firm level and then to link them with the data from the R\&D survey. This yielded a sample of almost 2800 firms, which was biased towards large, $R \& D$-intensive firms in manufacturing.

Perhaps the most straightforward way to examine this relationship, and to test the hypothesis of increasing costs of administration, would be to regress the logarithn of auxiliary-establishment employment on the logarithm of total employment. But 55 percent of the firms is our sample did not have any auxiliary establishments 24 Therefore we decided to examine this relationship nonparametrically, by ranking and grouping the firms into 10 size classes on the basis of total employment, and computing the ratio of auxiliary establishment employment (or managerial and administrative employment in these establishments) to total firm employment in each class. We computed both weighted ratios (i.e., the ratio of class means) and unweighted ratios (i.e., the class mean of the ratio); the latter is more sensitive to outliers, particularly among the smallest size classes. The results are presented in Table 3 . The data provide

23 See Lichtenberg (1989) for a discussion of these data.

24 Only 0.4 percent of the entire 3.4 million companies recorded in Census data had at least one auxiliary establishment. 
strong support for the hypothesis that both auxiliary establishment employment as a wole, and its administrative and managerial component, inctease more than proportionately with firm size. These findings appear to be inconsistent with the pyramidal nodel of administrative structure sketched above. We need to recognize, however, that because managers and administrators are employed in production establishments as well as in auxiliary establishments -- about 25 percent of production establishment employees are nonproduction workers -.. the data in Table 3 may partly reflect the fact that larger firms locate a larger fraction of their nonproduction activities in auxiliary establishments. Although it would be possible in principle to control and test for this, we have not had the opportunity to do this. Thus it is perhaps premature to reject the hypothesis of nonincreasing costs of administration.

\section{Summary and conclusions}

In this paper we have reported analyses of three large Census Bureau establishment- or firm-level data sets designed to yield insight into the effect of changes in ownership on the employment and wages of several important categories of workers. We were particulariy concerned with the effects on workers in auxiliary establishments, since it is there that top managers and administrators and many R\&D personnel are employed. Since the number of these (relatively highly-paid) workers is small compared to the number in production establishments, the effects of ownership change on them have not been captured or have been heavily masked in previous studies of the labor impact of takeovers.

One of our major findings is that employment growth is much lower -17 percentage points lower over 5 years -- in auxiliary establishments changing owners than in those not changing owners. Mean employment 
growth is slightly positive for establishments not changing owners, and is sharply negative for establishments changing owners. There is, however, no significant difference between changers and nonchangers in the growth of $\mathrm{R} \& \mathrm{D}$ employment.

The increase in payroll per employee was 9 percentage points lower among auxiliary establishments changing owners than it was anong other auxiliary establishments, controlling for industry and the initial wage rate. The relative decline in total compensation (including supplements to payrol1) was perhaps $1 / 3$ higher, about 12 percentage points.

The relative declines in employment and wages of workers in auxiliary establishments are about three times as great as the corresponding declines in production establishments. (In the latter case, the data indicate that the declines occur immediately before ownership change and are to a small extent reversed soon after. Unfortunately, due to the low frequency of the auxiliary establisbment data, we cannot determine how much of the employment and wage declines there occurred before vs after ownership change.) This implies that ownership change results in reductions in the wage and especially in the employment of auxiliary-establishment employees relative to those of production-establishment employees. Taken at face value, it implies that the ratio of auxiliaryestablishment to production-establishment employment declines 11.2 percent in firms involved in ownership change relative to firms not so involved. This translates into the elimination of 7.2 auxiliary establishment jobs for every 1000 production establishment jobs.

Some people express concern about the number of lawyers, investment bankers, and other highly-paid professionals devoted to facilitating or 
implatenting takeovers, and think that this may constitute a waste of valustis human resources. But the quantity and quality of labor engaged in the activity may not be high relative to the guantity and quality of central-office labor "saved" as a consequence of ownership change.

Because falled to account for auxiliary-establishment employment in oir earlier investigation of the effects of ownership change on productivity, we may have underestimated the productivity gain associated with ownership change by as imuch as 42 percent. The underestimate may not have been that great, however, if the declines in employment in auxiliary establishents changing owers are partialiy offset by increases in employment in other awiliary establishments owned by acquiring firms. There is no evidence that this is the case in the economy as a whole, but the data just for manufacturing (which may be more reliable) are consistent with the hypothesis of partially-offsetting employment increases in these other establishments. An admittedly crude attempt to adjust for this reduces from 16 to 11 percent the magnitude of the relative auxiliary-establishment employment decline of firms involved in ownership change. A more refined analysis of this issue is warranted, however.

In addition to revealing important differences between the effects of ownership change on auxiliary and production establishments, our analysis also indicated clear (although smaller) differences between its effects on production and nonproduction workers in production establishments. Only the production employees in these establishments appear to experience relative employment declines in connection with changes in ownership. Because the relative employment of nonproduction employees in production establishments doesn't decline, the overali ratio of 
"indirect" to "direct" labor isn't reduced in the course of ownership change. But the composition or locus of indirect labor does change significantly, as the fraction of it accounted for by auxiliary establishments is reduced.

The paper also provided some evidence concerning the relationship between firm size and administrative-intensity, defined as the ratio of auxiliary-establishment employment to total firm employment. Certain models of organizational structure imply that administrative-intensity should be constant or ever declining with respect to firm size throughout most of the range of firm size, but our data reveal an almost strictly increasing relationship throughout the range. Here, too, further research is needed to illuminate the nature of returns to scale in administration. 


\section{TABLE 1}

Distribution of Auxiliary-Establishment Employees by Type of Hork Performed,

All Industries, 1982

\section{Tyee of Work Performed}

Administrative and Managerial

Office and Clerical

Research, Development, and Testing

Warehousing

Electronic Data Processing

Direct Sales to Customers

Other Activities
Number of
employees

906

663

240

268

134

73

85

2570
Percent of all employees

$35.3 \%$

25.8

9.3

10.4

5.2

6.1

7.9

100.0

Total

Note: Number of employees in thousands. 
TABLE 2

Employment and Payroll of Auxiliary and Production Establishments

in Manufacturiag, $1963-1982$

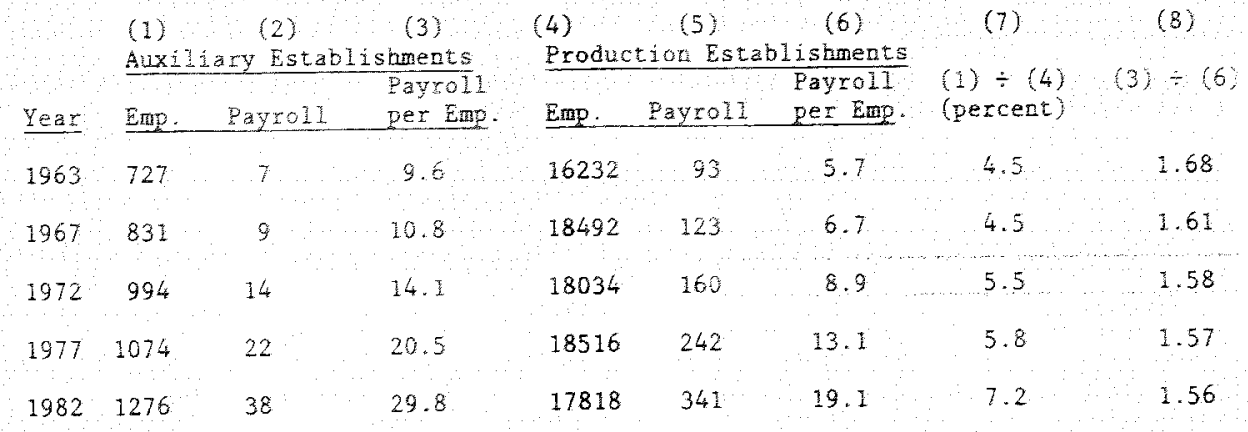

Note: Employment in thousands.

Payroll in billions of dollars.

Payroli per employee id thousands of dollars.

Solirce: U.S. Bureau of the Census,

1982 Census of Yanufactures, Subject Series MC82-\$-1 (Part I), General Summary, p. 1-98. 
TAELE 3

Mean Values of Emloynent and Wage

Levels and Changes, by Status

of Auxiliary Establiskment, I977-82

\begin{tabular}{|c|c|c|c|c|c|c|c|}
\hline Status & $\underline{N}$ & \multicolumn{2}{|c|}{$\begin{array}{l}\text { Mean Emp Loyment } \\
1977 \quad \frac{1982}{4}\end{array}$} & $\begin{array}{l}\text { Mean change } \\
\text { in } 1 \text { in (emp.), } \\
1977-82 \\
\end{array}$ & \multicolumn{2}{|c|}{$\frac{\text { Mear wage }}{1977 \text { 1982 }}$} & \multirow[t]{2}{*}{$\begin{array}{l}\text { Mean chat } \\
\text { in In (w } \\
1977-82\end{array}$} \\
\hline \multicolumn{7}{|c|}{ ALI INDUSTRIES } & \\
\hline Wo Change & 16730 & 93.2 & 99.6 & .031 & 17.6 & 26.8 & .397 \\
\hline $\begin{array}{l}\text { Changed } \\
\text { Owners }\end{array}$ & 2027 & 57.9 & 63.2 & $=.158$ & 14.7 & 22.1 & .392 \\
\hline Closed & 12184 & 34.0 & - & - & 15.7 & - & - \\
\hline Opened & 17219 & - & 45.0 & $-m$ & $m$ & 27.0 & - \\
\hline
\end{tabular}

\section{MANTEACTLRING}

$\begin{array}{lccccccc}\text { No Change } & 5390 & 156.3 & 174.3 & .042 & 20.0 & 30.1 & .398 \\ \begin{array}{l}\text { Changed } \\ \text { Owners }\end{array} & 633 & 93.2 & 101.0 & -.120 & 18.6 & 26.8 & .354 \\ \text { Closed } & 3437 & 52.5 & \ldots & -- & 17.6 & \ldots & \ldots \\ \text { Opened } & 4134 & \ldots & 65.3 & \ldots- & \ldots & 29.0 & \ldots\end{array}$

Note: Employment is number of workers.

Wage is payroli per empioyee, in thousands of dollars. 
TABLE 4

Estimated Effects of Ownership Change on
Employment and Wage in
Auxiliary and Production Establishments

Type of

Establishment

Industry

Effect of Ownership Change on:

Auxiliary

A11

Employment.

Wage

Auxiliary

$\therefore$

$-.167$

$-.092$

$(8.4)$

$(7.3)$

Auxiliary

Manufacturing

$\therefore .157$

$-.050$

$(4.6)$

(3.3)

Production

Manufacturing

$-.045$

$-.021$

$(5.4)$

(4.7)

12499

5949

18586

Note: Each of the effects reported above is at estimate of the coefficient $\beta_{1}$ in a regression of the form

ln $x_{i j t}=\beta_{1} O C_{i j t}+\beta_{2} 10 X_{i j t-5}+\gamma_{j}+H_{i j t}$

where $X$ denotes either employment or the wage rate; the subscript ijt refers to establishment i in industry $j$ in year $t ; O C$ equals 1 if the establishment changed owners between $t-5$ and $t$, and equals zero otherwise; $\gamma_{j}$ is a "fixed effect" for industry $j$; and is a classical disturbance. t is 1982 for auxiliary establishments, and is 1981 for production establishments. All equations included a complete set of 4 -digit SIC industry dummy variables. Numers in parentheses are $t$ - statistics. 


\section{TAEDE 5}

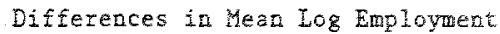

(Total, Production, and Nonproduction)

in Year t+k between production establishnents

changing and not changing owners

betreen $t-1$ and $t$

\begin{tabular}{|c|c|c|c|}
\hline Year & $\begin{array}{l}\text { Total } \\
\text { employment } \\
\text { (PP }+\mathrm{NP})\end{array}$ & $\begin{array}{l}\text { Eroduction- } \\
\text { worker } \\
\text { employment (PP) }\end{array}$ & $\begin{array}{l}\text { Wongroduction- } \\
\text { worker } \\
\text { employment (NP) }\end{array}$ \\
\hline $6-5$ & $\begin{array}{l}-.069 \\
(3.68)\end{array}$ & $\begin{array}{l}-.082 \\
(4.24)\end{array}$ & $\begin{array}{l}.012 \\
(1.95)\end{array}$ \\
\hline$t=\frac{1}{4}$ & $\begin{array}{l}-.072 \\
(4.11)\end{array}$ & $\begin{array}{l}-.086 \\
(4.79)\end{array}$ & $\begin{array}{c}.013 \\
(2.45)\end{array}$ \\
\hline$t-3$ & $\begin{array}{l}-.072 \\
(4.41)\end{array}$ & $\begin{array}{l}-.082 \\
(4.95)\end{array}$ & $\begin{array}{l}.010 \\
(1.97)\end{array}$ \\
\hline$t-2$ & $\begin{array}{l}-.103 \\
(6.89)\end{array}$ & $\begin{array}{l}-.116 \\
(7.61)\end{array}$ & $\begin{array}{c}.017 \\
(3.62)\end{array}$ \\
\hline$\frac{1}{2}-1$ & $\begin{array}{c}-.119 \\
(8.03)\end{array}$ & $\begin{array}{l}-.133 \\
(8.81)\end{array}$ & $\left\{\begin{array}{l}.012 \\
\{2.61\}\end{array}\right.$ \\
\hline$t$ & $\begin{array}{l}-.132 \\
(9.48)\end{array}$ & $\begin{array}{l}-.153 \\
(10.73)\end{array}$ & $\begin{array}{l}.012 \\
(2.66)\end{array}$ \\
\hline$t+i$ & $\begin{array}{l}-.131 \\
(8.67)\end{array}$ & $\begin{array}{l}-.145 \\
(9.33)\end{array}$ & $\begin{array}{c}.012 \\
(2.39)\end{array}$ \\
\hline$t+2$ & $\begin{array}{l}-.120 \\
(7.28)\end{array}$ & $\begin{array}{l}-.131 \\
(7.78)\end{array}$ & $(1.76)$ \\
\hline$t+3$ & $\begin{array}{l}-.118 \\
(6.72)\end{array}$ & $\begin{array}{l}-.125 \\
(6.69)\end{array}$ & $\begin{array}{c}.011 \\
(1.88)\end{array}$ \\
\hline$t+4$ & $\begin{array}{l}-.124 \\
(6.54)\end{array}$ & $\begin{array}{l}-.126 \\
(5.97)\end{array}$ & $\begin{array}{c}.015 \\
(2.38)\end{array}$ \\
\hline
\end{tabular}


TABLE 6

Ratio of Cestral-office Employment to

Total Firm Employment by Size of Firm

\begin{tabular}{|c|c|c|c|c|c|c|}
\hline \multirow{2}{*}{$\begin{array}{l}\text { Size } \\
\text { Class" }\end{array}$} & \multirow[t]{2}{*}{$\begin{array}{l}\text { Mean } \\
\text { cotal } \\
\text { finm } \\
\text { employment } \\
\end{array}$} & \multicolumn{2}{|c|}{$\begin{array}{l}\text { Ratio of } \\
\text { total central- } \\
\text { office employment } \\
\text { to total firm } \\
\text { employment }\end{array}$} & \multicolumn{2}{|c|}{$\begin{array}{l}\text { Ratio of } \\
\text { Administrative } \\
\text { and managerial } \\
\text { employment to total } \\
\text { firm employment }\end{array}$} & $\begin{array}{l}\text { Proportion } \\
\text { of firms } \\
\text { owning at } \\
\text { least one } \\
\text { auxiliary } \\
\text { establishment }\end{array}$ \\
\hline & & Weighted & Unweighted & Weighted & Unweighted & \\
\hline 0 & 44 & $0.5 \%$ & $5.0 \%$ & $0.2 \%$ & $5.2 \%$ & $3 \%$ \\
\hline 1 & 150 & 2.1 & 2.8 & 0.6 & 1.2 & 12 \\
\hline 2 & 284 & 4.4 & 4.7 & 1.5 & 1.6 & 23 \\
\hline 3 & 458 & 2.8 & 4.0 & 1.1 & 1.6 & 24 \\
\hline 4 & 666 & 3.8 & 4.4 & 1.5 & 1.6 & 34 \\
\hline 5 & 1029 & 6.5 & 6.6 & 2.0 & 2.3 & 50 \\
\hline 6 & 1670 & 6.0 & 7.5 & 2.2 & 2.6 & 60 \\
\hline 7 & 3147 & 7.1 & 8.5 & 2.9 & 3.1 & 69 \\
\hline 8 & 7317 & 10.0 & 10.4 & 3.6 & 3.7 & 84 \\
\hline 9. & 36163 & 11.3 & II.I & 3.8 & 3.8 & 91 \\
\hline
\end{tabular}

*Firms were ranked and grouped into 10 size classes on the basis of total

firm employwent. There are about 278 firms in each size class. 


\section{REFERENCES}

Auerbach, Alan J. (1988), "Introduction," in Corporace Takeovers: Causes and Consequences, Alan Auerbach (ed.) (Chicago: Unit, of Chicaso Press

Feckana, Martin J. (1977), "Management Production Functions and the Theory of the Firra," Journal of Econonic Theory 14, 1-18.

Blair, Margare (1988), "An Empizical Test of the Connetion Betucen Tree Cash Flow and Takeover Waves:" Unpub. Paper, Brookings Instituion, Decemer.

Brom, Charles, and Medoff, James I. (1988), "Whe Impact of Firm Acquisitions on Labor," in Corporate Takeovers: Causes and Conseguences, Alan Auerhach (ed.) (Chicago: University of Chicago Press), $9-25$.

Dunne, Timothy; Roberts, Hark J.; and Samuelson, Iarry (1988), "The Growth and Failure of hamufacturing Plants," unpub. paper, Pensylvania State University, January.

Farber, Henry S. (1988), "Coment" on Brown zad Medoff, in Corporate Takeovers: Causes and Consequences, Alan Auerbach (ed.) (Chicago: Jaiversity of Chicago Press).

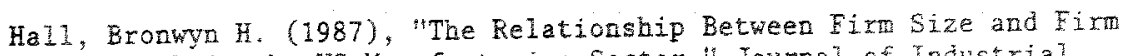
Growth in the US Manufacturing Sector," Journal of Industrial Economics XXXV, 383-606.

(1988), "the sficet of Takeover Activity on Corporate Research and Development," in Corgorate Takeovers: Causes and Consequences, Alan Auerbach (ed.) (Chicago: University of Cricago Press), 9-25.

Icahn, Carl C. (1989), "The Case for Takeovers," New York Times: van. 29 , Section $6, p \cdot 34$.

Kapian, Steven N. (1988), "Sources of Value in Management Buyouts," unpub. doctoral dissertation, Harvard University.

Kravis, Henry (1989), "Greed Really Turns Me Off," Fortune, January 2 , 69-71.

Lichtenberg, Frank (1988), "Estimation of the Interial Adjustment Costs Model Using Longitudinal Establishment Data," Review of Economics and Statistics, August, $421-430$.

Policy, forthcoming.

(1989), "Issues in Measuring Industrial R\&D," Research and Siegel, Donaid (1987), "Productivity and 
Changes in Ownership of Manufacturing Plants" Brookings Papers on Econonic Activity, $643-673$.

Shleifer, Andre, and Vishny, Robert (1988), Value Maximization and the Acquisition Process" Journal of Economic Perapectives $2,7-20$.

Starbuck, H.H. (1964), "Organizational Growth and Development," in Handbook of Organizations, J.G. March (ed.) (Chicago: Rand Mchaliy).

The Economist (1989), "A work-out for Corporate America," January 7 , $55-56$

U.S. Bureau of Labor Statistics (1980), Employment and Earnings Vol. 27 No: 6, June. U.S. Bureau of the Census $(1986)$, 1982 Enterprise Statistics, Auxiliary
Establishment Report ES82-2 (Washington: U.S. Government Erinting Office).

$(198), \frac{1982 \text { Census of Manufactures, Subject Series }}{\text { (n.S. Government }}$ MC82-S-1 (Part 1), General Sumary (hashington: U.S. Government Printing office). 